\title{
EXPANSÃO EDUCACIONAL NO SUDESTE E MIGRAÇÃO EM MINAS GERAIS: IMPACTOS NA ALFABETIZAÇÃO DA POPULAÇÃO DE ITUIUTABA
} (1956-1971)

\author{
Luciene Teresinha de Souza Bezerra \\ Betania de Oliveira Laterza Ribeiro \\ José Carlos Souza Araujo
}

\begin{abstract}
RESUMO
Com este estudo, buscou-se explorar os impactos da migração e da expansão educacional nos índices de analfabetismo no Brasil. No processo de desenvolvimento nacional no período de 1950-1960, a industrialização e urbanização atraíram para a cidade uma massa de população campesina que, até então, superava a população urbana, caso se considerasse o Sudeste ou a própria Minas Gerais. Objetivou-se compreender a influência da migração nas taxas de analfabetismo desse estado, focalizando o município de Ituiutaba entre 1956 e 1971. Como pesquisa documental, este estudo se ancorou em atas da Câmara Municipal, em matérias jornalísticas, em relatos orais e em dados estatísticos. Os resultados mostram que os dados locais põem em xeque eventuais consensos. Por exemplo, esse município experimentou um processo de migração para o campo - e não do meio rural para a cidade o que ampliou suas taxas de analfabetismo. Nesse caso, o número de escolas rurais superou o de escolas urbanas, quando a tendência da expansão educacional era de feição urbana, como são os grupos escolares. Ainda assim, esse município apresentou taxas de analfabetismo que superavam a média regional e nacional.
\end{abstract}

Palavras-chave: Desenvolvimento nacional; Industrialização; Urbanização; Analfabetismo; Escolas rurais.

\section{EDUCATION SPREAD IN SOUTHEAST AND MIGRATION IN MINAS GERAIS STATE: IMPACTS ON LITERACY OF ITUIUTABA CITY POPULATION} (1956-1971)

\begin{abstract}
This study aimed to explore the impacts of migration and educational expansion on illiteracy rates in Brazil. In the years 1950-60, Brazil entered a development period, which was marked not only by industrialization and urbanization but also by a mass of rural population, which until then exceeded the urban population - if we consider the Southeast region (and Minas Gerais). This study aimed to understand the influence of migration on illiteracy rates of this state, by focusing on Ituiutaba municipality between 1956 and 1971. Based on documents, this study drew from sources such as City Hall minutes, newspaper articles, oral accounts and statistics. Results show that the particular data is different from expected. For example, Ituiutaba experienced a migration process which led people to rural areas, and not the other way round, as it the national trend. It was natural then that the number of rural schools overcame urban one, when the trend of educational expansion had the city in mind. Still, Ituiutaba city had illiteracy rates that exceeded the regional and national average.
\end{abstract}

Keywords: National development; Industrialization; Urbanization; Illiteracy; Rural schools. 


\section{Introdução}

A compreensão histórica da educação pública, no Brasil, tende a beneficiar-se da lógica dialética no que se refere à consideração do geral, do particular e do local na análise. A consciência dessa possibilidade permite uma compreensão mais abrangente das relações entre escolarização e precariedade estrutural do ensino público, uma vez que o dado local pode oferecer subsídios que permitem pôr em xeque os consensos e as tentativas de generalizar. Dicotomizar "[...] o particular e o universal, o específico e o geral [...]”, como afirma Buffa (2002, p. 26), é ignorar que tais categorias se imbricam, inter-relacionam-se, correlacionam-se e convivem, ou seja, não são necessariamente dicotômicas.

A título de contextualização, há de se considerar o caso da alfabetização. Na década de 1920, a taxa de brasileiros alfabetizados na faixa etária de 5 a 19 anos era de 9\%; já, na década de 1940, atingiu a 21,43\%. Disso se deduz uma ampliação expressiva do número de matrículas, pois, “[...] em 1920, mais de $90 \%$ da população escolarizável não frequentava a escola" (ROMANELLI, 1978, p. 64). No período de 1957-1966, a expansão da escolarização, sobretudo no Sudeste, eleva o percentual acima de 53\%. Ainda assim, não se pode dizer que a elevação tenha sido uniforme. Estado de projeção econômica e política, Minas Gerais apresentava índices de analfabetismo alarmante; e, no que se refere ao município de Ituiutaba, no Triângulo Mineiro, a migração talvez tenha sido uma variável influente não só no que diz respeito à manutenção do analfabetismo, mas também a sua ampliação.

Esse município se singulariza no que se refere ao plano geral nas relações entre migração e escolarização. De acordo com o plano nacional, o movimento de expansão educacional era o de criar mais escolas nas cidades - os grupos escolares. No entanto, em Ituiutaba, ocorreu o inverso: foi necessária a criação de mais escolas rurais, visto que o meio rural recebera levas de migrantes do norte de Minas Gerais e do Nordeste, por exemplo, nas décadas de 1950 e 1960. Se, nesse momento, o fluxo da migração nacional era do campo para a cidade, em Ituiutaba, o alvo da migração foi o campo.

Nessas décadas, o município de Ituiutaba consolidou-se economicamente, chegando a ser denominado de "capital do arroz", tal era a força econômica da rizicultura. Não por acaso, atraiu uma massa de migrantes em busca de melhores condições de vida, muitos advindos de áreas do sertão mineiro e nordestino. Uma vez instalados no meio rural, passaram a compor a população campesina original, por si só, maior que a da sede municipal. Esse aumento impôs a necessidade de criar escolas para suprir a demanda educacional das famílias que se estabeleceram nas fazendas. Dessa forma, em um dado momento, havia quatro vezes mais escolas no campo que na cidade. Se, no período de 1910 a 1946, a cidade de Ituiutaba contou com uma escola pública para o curso elementar, até 1947, ela possuía somente dois grupos escolares ${ }^{1}$.

Com esse desenvolvimento, a sociedade e o poder público de um município de projeção econômica regional e nacional, assim como o país, foram incapazes de evitar um índice de analfabetismo de 57\%, na década 1960, mais expressivo que as taxas de Minas Gerais. Diante disso, pode-se falar em contradição nas relações entre um desenvolvimento municipal econômico ascendente e sua desarticulação com o ensino público. Compreendese a estrutura do processo dialético como uma contradição, sendo este um condutor do mundo social, onde se inserem os homens. Revela o movimento da própria existência, por meio de um processo dinâmico, em que a contradição é um eixo imprescindível para a sociedade. Portanto, este processo é tenso, sempre marcado pelo o que já foi e o ainda-não, não sendo. Nesse sentido, “[...] todo real é um processo que contém, sem encerrar, o 
possível numa unidade de contrários" (CURY, 1995, p. 31). Ignorá-la seria considerar a realidade como algo estático, seria retirar do real, o movimento.

Com pretensões mais descritivas do que de análise problematizadora, este estudo ${ }^{2}$ explora esse contexto, ao buscar situar o município de Ituiutaba - a cidade e o campo - no processo de expansão educacional, alinhado aos projetos políticos nacionais de impacto na economia e na sociedade local, sobretudo na educação. O propósito é ampliar o entendimento do processo histórico do ensino primário em sua projeção local e regional, de acordo com o processo político-educacional, no período entre 1956 e 1971. O estudo objetivou construir uma compreensão a respeito da migração como fator influente no aumento da população em geral e, em particular, da analfabeta, principalmente, a partir da década de1950.

Para tanto, esta pesquisa recorre a fontes estatísticas, à imprensa local, às atas da Câmara Municipal e aos relatos orais, a fim de discernir permanências, resistências e recriações no processo de expansão da escolarização. O levantamento e a sistematização dessas fontes produziram dados que foram organizados para serem lidos no terreno circunscrito pelas categorias de análise - contexto histórico e circunstância de criação de escolas - sugeridas por Nosella e Buffa (2005). Entram em cena a expansão da escola pública no Sudeste, em Minas Gerais, e o êxodo urbano, marcante no município, desde meados da década de 1950, quando houve a migração de famílias trabalhadoras para o meio rural de Ituiutaba; e, a partir dos anos de 1970, quando muitos desses migrantes trabalhadores se rumaram para o meio urbano em busca das condições de trabalho que a mecanização do campo subtraíra, e de escolas que foram fechadas em decorrência do esvaziamento do meio rural.

\section{Expansão educacional no Sudeste e em Minas Gerais}

No período de 1950 a 1960, houve transformações significativas na estrutura social do país, alinhadas ao desejo republicano de modernizá-lo, ou seja, de anular, de vez, o conservadorismo e o tradicionalismo que resistiram à renovação imposta pela República, ainda, entranhados em alguns setores. Beskow (1999, p. 56) entende tais mudanças como indícios da entrada do país em condições "[...] mais avançadas de industrialização [...]", com "[...] mercado doméstico crescente [...]", com políticas de importação protecionistas e favoráveis a "[...] empresários já instalados [...]", com investimentos vultuosos do Estado e "[...] fortes investimentos externos [...]" na indústria, por exemplo, de energia e transportes.

Em outros termos, o Estado deu mostras de seu interesse em industrializar o país, procurando diminuir as importações e ampliar o capital. Para isso, Juscelino Kubitscheck instituiu um Plano de Metas, prevendo, inclusive, a construção de uma nova sede administrativa no Centro-Oeste brasileiro, de tal modo que Brasília materializou o esforço de estabelecer as bases da infraestrutura para o desenvolvimento do capital e estendê-la para o interior do país.

Mudou-se o perfil demográfico: de predominantemente rural para urbano. A agricultura perdeu importância na balança comercial, ainda que produzir alimentos básicos era e continua sendo primordial para sustentar a massa trabalhadora urbana. Conforme Beskow (1999, p. 70): "No processo de industrialização substitutiva de importações, coube ao setor agrícola uma série de funções, como: o suprimento de alimentos baratos para a força de trabalho do setor industrial e das demais atividades urbanas [...]", dentre outras funções. 
Esse período coincide com a ascensão de Juscelino Kubitschek à presidência da República, cujo Plano de Metas pretendeu alcançar o desenvolvimento de cinco décadas, em cinco anos. O plano consistia em 30 metas para educação, energia e transportes, dentre outros; sua síntese, e talvez o símbolo maior, foi a transferência da capital, então no Rio de Janeiro, para o planalto central, onde seria erguida Brasília, o novo Distrito Federal. Como afirma Skidmore (2007, p. 205), "[...] o Governo Kubitschek seguiu uma política de nacionalismo desenvolvimentista". A ideologia do nacional-desenvolvimentismo alinhouse por meio da abertura do país que possibilitou a entrada de organizações estrangeiras de bens de consumo duráveis para finalizar o processo de substituição de importações.

Certamente, o governo conseguiu atingir sua meta de industrialização. Mas, conforme Saviani (2007, p. 350): "Manifestou-se aí a contradição entre o modelo econômico, de caráter desnacionalizante, e a ideologia política nacionalista, que estaria na base da crise dos anos iniciais da década de 1960, que desembocou no internacionalismo autoritário em sua vertente militarista". Educação e cultura ocuparam o quarto lugar nas prioridades. Na posição ocupada pelo setor educacional, as verbas previstas somavam $3,4 \%$ do produto interno bruto; percentual que contrasta com os 93\% previstos para energia, transportes e indústrias de base (SILVA, 2015). No entanto, "[...] também se realiza a disseminação do ensino privado, confessional ou não, que concorre com a dimensão pública, seja auxiliando-a ou com ela estabelecendo parceria, seja socorrendo a nascente pressão pela escolarização" (ARAUJO, 2006, p. 214).

Em decorrência disso, os investimentos do Estado deveriam convergir para o progresso da educação pública, em especial o nível primário, que precisava se expandir com urgência, atendendo às camadas populares. Nas tabelas, a seguir, apresentam-se dados do quantitativo de alunos, referentes à realidade da educação em nível nacional, particular e público (estadual e municipal), respectivamente, de acordo com a sua dependência administrativa.

Tabela 1. Dados quantitativos de alunos, segundo a administração escolar na região Sudeste, 1957-1971

\begin{tabular}{cccccccccc}
\hline & SUDESTE & FEDERAL & $\%$ & ESTADUAL & $\%$ & MUNICIPAL & $\%$ & PARTICULAR & $\%$ \\
\hline 1957 & 2.745 .764 & 1.080 & 0,04 & 1.816 .066 & 66,14 & 631.198 & 22,99 & 297.420 & 10,83 \\
1958 & 2.848 .199 & 1.011 & 0,04 & 1.862 .739 & 65,40 & 703.310 & 24,69 & 281.139 & 9,87 \\
1959 & 2.991 .684 & 2.625 & 0,09 & 1.933 .448 & 64,63 & 750.422 & 25,08 & 305.189 & 10,20 \\
1960 & 3.156 .600 & 3.324 & 0,11 & 2.331 .760 & 73,87 & 510.221 & 16,16 & 311.295 & 9,86 \\
1961 & 3.275 .720 & 2.492 & 0,08 & 2.485 .408 & 75,87 & 483.768 & 14,77 & 304.052 & 9,28 \\
1962 & 3.547 .846 & 4.574 & 0,13 & 2.679 .682 & 75,53 & 544.809 & 15,36 & 318.781 & 8,98 \\
1963 & 4.466 .056 & 7.331 & 0,16 & 3.376 .575 & 75,61 & 699.982 & 15,67 & 382.168 & 8,56 \\
1964 & 4.983 .134 & 6.846 & 0,14 & 3.805 .789 & 77,07 & 626.380 & 12,68 & 499.119 & 10,11 \\
1965 & 4.910 .859 & 8.734 & 0,18 & 3.868 .794 & 78,78 & 571.315 & 11,63 & 462.016 & 9,41 \\
1966 & 5.109 .989 & 10.408 & 0,20 & 4.107 .703 & 80,39 & 531.044 & 10,39 & 460.834 & 9,02 \\
1967 & 5.267 .598 & 8.650 & 0,16 & 4.157 .903 & 78,94 & 625.879 & 11,88 & 475.166 & 9,02 \\
1968 & 5.411 .195 & 8.813 & 0,16 & 4.164 .827 & 76,97 & 746.004 & 13,79 & 491.551 & 9,08 \\
1969 & 5.525 .471 & 11.056 & 0,20 & 4.224 .739 & 76,46 & 787.233 & 14,25 & 502.443 & 9,09 \\
1970 & 5.642 .496 & 13.440 & 0,24 & 4.317 .879 & 76,52 & 823.970 & 14,60 & 487.207 & 8,64 \\
1971 & 5932.238 & 9.366 & 0,16 & 4.467 .672 & 75,31 & 959.164 & 16,17 & 496.036 & 8,36 \\
\hline
\end{tabular}

Fonte: IBGE (2010).

A região Sudeste pouco alterou em relação aos percentuais em níveis federal e particular, embora este tenha caído em 2,5\%, ao final do período, na participação geral. Já, no que diz respeito ao ensino público, os estados apresentaram uma parcela mais significativa no total das matrículas, isto é, subiu pouco mais de $9 \%$, em relação ao todo. Por outro lado, os municípios tiveram sua participação diminuída em quase 7\%. 
Tabela 2. Dados quantitativos de alunos, segundo a administração escolar em Minas Gerais, $1957-1971$

\begin{tabular}{lccccccccc}
\hline & $\begin{array}{c}\text { MINAS } \\
\text { GERAIS }\end{array}$ & FEDERAL & $\%$ & ESTADUAL & $\%$ & MUNICIPAL & $\%$ & PARTICULAR & $\%$ \\
\hline 1957 & 923.230 & 1.080 & 0,12 & 578.579 & 62,67 & 279.315 & 30,25 & 64.256 & 6,96 \\
1958 & 879.501 & 1.011 & 0,11 & 552.040 & 62,77 & 272.711 & 31,01 & 53.739 & 6,11 \\
1959 & 939.085 & 2.625 & 0,28 & 579.373 & 61,69 & 300.765 & 32,03 & 56.322 & 6,00 \\
1960 & 1.020 .664 & 3.324 & 0,32 & 697.135 & 68,30 & 265.640 & 26,03 & 54.565 & 5,35 \\
1961 & 1.033 .971 & 2.492 & 0,24 & 739.246 & 71,50 & 244.228 & 23,62 & 48.005 & 4,64 \\
1962 & 1.157 .189 & 3.740 & 0,32 & 795.527 & 68,75 & 286.411 & 24,75 & 71.511 & 6,18 \\
1963 & 1.437 .591 & 3.853 & 0,27 & 1.004 .414 & 69,86 & 356.023 & 24,77 & 73.301 & 5,10 \\
1964 & 1.577 .472 & 4.670 & 0,30 & 1.160 .373 & 73,56 & 340.321 & 21,57 & 72.108 & 4,57 \\
1965 & 1.714 .491 & 5.643 & 0,33 & 1.322 .776 & 77,15 & 314.778 & 18,36 & 71.294 & 4,16 \\
1966 & 1.782 .063 & 8.176 & 0,46 & 1.443 .107 & 80,98 & 277.666 & 15,58 & 53.114 & 2,98 \\
1967 & 1.853 .092 & 6.172 & 0,33 & 1.459 .764 & 78,78 & 338.976 & 18,29 & 48.180 & 2,60 \\
1968 & 1.798 .228 & 5.368 & 0,30 & 1.306 .018 & 72,63 & 436.487 & 24,27 & 50.355 & 2,80 \\
1969 & 1.830 .082 & 9.840 & 0,54 & 1.321 .637 & 72,22 & 446.604 & 24,40 & 52.001 & 2,84 \\
1970 & 1.850 .944 & 8.205 & 0,44 & 1.342 .928 & 72,55 & 451.566 & 24,40 & 48.245 & 2,61 \\
1971 & 1.941 .182 & 7.246 & 0,37 & 1.358 .795 & 70,00 & 528.015 & 27,20 & 47.126 & 2,43 \\
\hline Fonte: IBGE (1972). & & & & & & & &
\end{tabular}

Ao se articular a quantidade de alunos por escola com a sua respectiva dependência administrativa e ainda com a sua localização, observa-se que, no ensino particular, houve redução de matrículas em Minas Gerais: de 6,96\%, em 1957, passou para 2,43\%, em 1971; assim como ocorreu no ensino municipal, cuja queda se aproximou de $3 \%$.

Nas escolas públicas em que houve oscilação, ao longo do período, a matrícula aumentou em quase 7,5\%. Uma vez que a participação nas escolas municipais, em Minas Gerais, é superior à das escolas do Sudeste, esse estado apresenta participação mais expressiva, assim como também é a presença do ensino particular no Sudeste em relação a Minas.

Tabela 3. Unidades escolares por dependência administrativa no Sudeste, 1957-1971

\begin{tabular}{lccccccccc}
\hline & SUDESTE & FEDERAL & $\%$ & ESTADUAL & $\%$ & MUNICIPAL & $\%$ & PARTICULAR & $\%$ \\
\hline 1957 & 31.076 & 15 & 0,05 & 15.072 & 50,75 & 12.578 & 40,48 & 2.711 & 8,72 \\
1958 & 32.278 & 17 & 0,05 & 16.303 & 50,51 & 13.291 & 41,18 & 2.667 & 8,26 \\
1959 & 33.443 & 57 & 0,17 & 16.640 & 49,76 & 13.910 & 41,59 & 2.836 & 8,48 \\
1960 & 34.869 & 52 & 0,15 & 19.635 & 56,31 & 12.299 & 35,27 & 2.883 & 8,27 \\
1961 & 35.435 & 28 & 0,08 & 21.090 & 59,52 & 11.503 & 32,46 & 2.814 & 7,94 \\
1962 & 37.177 & 46 & 0,12 & 21.041 & 56,60 & 13.207 & 35,52 & 2.883 & 7,76 \\
1963 & 38.447 & 50 & 0,13 & 22.587 & 58,75 & 12.930 & 33,63 & 2.880 & 7,49 \\
1964 & 42.001 & 59 & 0,14 & 26.452 & 62,98 & 12.203 & 29,05 & 3.287 & 7,83 \\
1965 & 42.719 & 75 & 0,18 & 28.284 & 66,21 & 11.281 & 26,41 & 3.079 & 7,20 \\
1966 & 44.051 & 118 & 0,27 & 30.955 & 70,27 & 9.962 & 22,61 & 3.016 & 6,85 \\
1967 & 39.021 & 62 & 0,17 & 25.349 & 64,96 & 10.727 & 27,49 & 2.877 & 7,38 \\
1968 & 39.327 & 68 & 0,17 & 23.190 & 58,96 & 13.059 & 33,20 & 3.016 & 7,67 \\
1969 & 45.860 & 50 & 0,11 & 28.136 & 61,35 & 14.625 & 31,89 & 3.049 & 6,65 \\
1970 & 45.756 & 74 & 0,16 & 28.680 & 62,68 & 13.934 & 30,45 & 3.068 & 6,71 \\
1971 & 48.057 & 49 & 0,10 & 29.762 & 61,93 & 51.052 & 31,32 & 3.194 & 6,65 \\
\hline
\end{tabular}

Fonte: IBGE (1972).

Sobre a dependência administrativa das unidades escolares no Sudeste e em Minas, nota-se que, na região, esse estado apresenta aumento na participação de alunos, entretanto, verifica-se que há uma queda no que se refere à participação em nível municipal. Já, as escolas particulares apresentam contraste em relação ao Sudeste. Enquanto em Minas não 
houve mudança no número de participação, nas escolas dos municípios, observa-se um aumento de matrículas, em uma proporção equivalente à perda matricular das particulares. Enfim, o estado de Minas apresenta um número de escolas municipais, em dobro, em relação às estaduais, conforme Tabela 4. No Sudeste, ocorre o contrário, embora isso não signifique que o número de alunos matriculados no município e estado seja na mesma proporção.

Tabela 4. Unidades Escolares por dependência administrativa em Minas Gerais, 1957-1971

\begin{tabular}{ccccccccccc}
\hline & \multirow{2}{*}{ MG } & \multirow{2}{*}{ EVOLUÇÃO } & $\begin{array}{c}\text { FEDERA } \\
\text { L }\end{array}$ & $\%$ & \multirow{2}{*}{ ESTADUAL } & $\%$ & \multirow{2}{*}{ MUNICIPAL } & $\%$ & \multirow{2}{*}{ PRIVADA } & $\%$ \\
\hline 1957 & 11.080 & - & 15 & 0,14 & 3.334 & 30,09 & 7.223 & 65,19 & 508 & 4,58 \\
1958 & 11.303 & 102,01 & 17 & 0,15 & 3,401 & 30,09 & 7.354 & 65,06 & 531 & 4,70 \\
1959 & 11.870 & 105,02 & 57 & 0,48 & 3,411 & 28,74 & 7.843 & 66,07 & 559 & 4,71 \\
1960 & 12.667 & 106,71 & 52 & 0,41 & 5.165 & 40,77 & 6.926 & 54,68 & 524 & 4,14 \\
1961 & 12.672 & 100,04 & 28 & 0,22 & 5.647 & 44,56 & 6.525 & 51,49 & 472 & 3,73 \\
1962 & 13.581 & 107,17 & 40 & 0,30 & 4.944 & 36,40 & 7.956 & 58,58 & 641 & 4,72 \\
1963 & 13,924 & 102,52 & 36 & 0,26 & 5.144 & 36,94 & 8.160 & 58,60 & 584 & 4,20 \\
1964 & 15.710 & 112,83 & 49 & 0,31 & 6.791 & 43,23 & 8.223 & 52,34 & 647 & 4,12 \\
1965 & 16.181 & 103,00 & 60 & 0,37 & 7.787 & 48,12 & 7.722 & 47,72 & 612 & 3,79 \\
1966 & 16.505 & 102,00 & 109 & 0,66 & 9.153 & 55,46 & 6.804 & 41,22 & 439 & 2,66 \\
1967 & 16.829 & 101,96 & 47 & 0,28 & 8.556 & 50,84 & 7.829 & 46,52 & 397 & 2,36 \\
1968 & 16.042 & 0,9532 & 36 & 0,23 & 5.493 & 34,24 & 10.121 & 67,09 & 392 & 2,44 \\
1969 & 16.878 & 105,21 & 44 & 0,26 & 5.241 & 31,05 & 11.180 & 66,24 & 413 & 2,45 \\
1970 & 16.136 & 0,9560 & 46 & 0,29 & 5.107 & 31,64 & 10.570 & 65,51 & 413 & 2,56 \\
1971 & 17.092 & 105,92 & 38 & 0,22 & 5.140 & 30,07 & 11.500 & 67,28 & 414 & 2,43 \\
\hline
\end{tabular}

Fonte: IBGE (1972).

Nesse contexto de desenvolvimento acelerado, a educação foi submetida a um processo de expansão da mesma natureza, sobretudo, a partir da segunda metade da década de 1950 até o início do decênio de 1970. A escolarização expandiu-se com vigor na região Sudeste, conforme tabela, a seguir.

Tabela 5. Escolas do Sudeste e de Minas Gerais, segundo localização das unidades escolares, 1957-1971

\begin{tabular}{ccccccccccc}
\hline & $\begin{array}{c}\text { SUDESTE } \\
\text { TOTAL }\end{array}$ & $\begin{array}{c}\text { ESCOLAS } \\
\text { URBANA } \\
\text { S }\end{array}$ & $\%$ & $\begin{array}{c}\text { ESCOLAS } \\
\text { RURAIS }\end{array}$ & $\%$ & $\begin{array}{c}\text { MINAS } \\
\text { GERAIS }\end{array}$ & $\begin{array}{c}\text { ESCOLAS } \\
\text { URBANAS }\end{array}$ & $\begin{array}{c}\text { ESCOLAS } \\
\text { RURAIS }\end{array}$ & $\%$ \\
\hline 1957 & 31.076 & 9.220 & 29,67 & 21.856 & 70,33 & 11.080 & 2.812 & 25,38 & 8.268 & 74,62 \\
1958 & 32.278 & 9.352 & 28,97 & 22.926 & 71,03 & 11.303 & 2.852 & 25,23 & 8.451 & 74,77 \\
1959 & 33.443 & 9.768 & 29,21 & 23.675 & 70,79 & 11.870 & 2.985 & 25,15 & 8.885 & 74,85 \\
1960 & 34.869 & 9.878 & 28,33 & 24.991 & 71,67 & 12.667 & 2.945 & 23,25 & 9.722 & 76,75 \\
1961 & 35.435 & 9.962 & 28,11 & 25.473 & 71,89 & 12.672 & 2.853 & 22,51 & 9.819 & 77,49 \\
1962 & 37.177 & 10.216 & 27,48 & 26.961 & 72,52 & 13.581 & 2.923 & 21,52 & 10.658 & 78,48 \\
1963 & 38.447 & 10.564 & 27,48 & 27.883 & 72,52 & 13.924 & 2.724 & 19,56 & 11.200 & 80,44 \\
1964 & 42.001 & 12.210 & 29,07 & 29.791 & 70,93 & 15.710 & 3.082 & 19,62 & 12.628 & 80,38 \\
1965 & 42.719 & 12.968 & 30,36 & 29.751 & 69,64 & 16.181 & 3.445 & 21,29 & 12.736 & 78,71 \\
1966 & 44.051 & 11.831 & 26,86 & 32.220 & 73,14 & 16.505 & 3.044 & 18,44 & 13.461 & 81,56 \\
1967 & 39.021 & 9.619 & 24,65 & 29.402 & 75,35 & 16.829 & 2.934 & 17,43 & 13.895 & 82,57 \\
1968 & 39.327 & 10.203 & 25,94 & 29.124 & 74,06 & 16.042 & 3.044 & 18,98 & 12.998 & 81,02 \\
1969 & 45.860 & 12.123 & 26,43 & 33.737 & 73,57 & 16.878 & 3.125 & 18,52 & 13.753 & 81,48 \\
1970 & 45.756 & 11.932 & 26,08 & 33.824 & 73,92 & 16.136 & 3.223 & 19,97 & 12,913 & 80,03 \\
1971 & 48.057 & 12.312 & 25,62 & 35.745 & 74,38 & 17.092 & 3.262 & 19,08 & 13.830 & 80,92 \\
\hline
\end{tabular}

Fonte: IBGE (2010).

Possivelmente seja em razão desse avanço que o volume de pessoas na faixa etária de 5 a19 anos, na escola, tenha se elevado a 53,72\% em 1970. Ante a situação das 
primeiras décadas do século XX, era evidente o progresso alcançado, pois, nessa época, segundo Romanelli (1978, p.64) “[...] mais de 90\% de tal população escolarizável não frequentava a escola". A tabela, a seguir, expõe dados relativos a esse avanço em relação ao número de matrículas.

Tabela 6. Crescimento populacional e escolarização da população brasileira em idade escolar, faixa etária de 5 a19 anos - 1920-1970

\begin{tabular}{|c|c|c|c|c|c|c|c|}
\hline $\begin{array}{l}\text { Z } \\
\text { O }\end{array}$ & 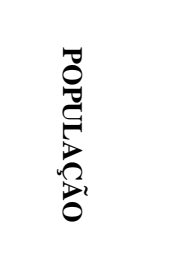 & 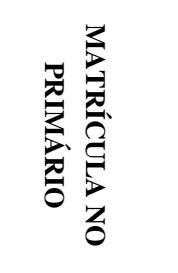 & 恋 & 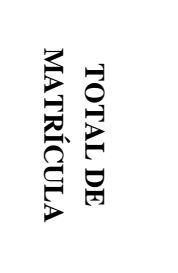 & 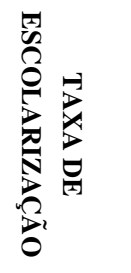 & 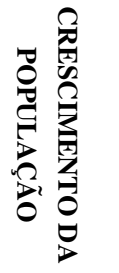 & 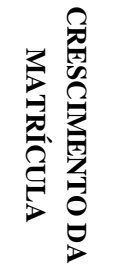 \\
\hline 1920 & 12.703 .077 & 1.033 .421 & 109.281 & 1.142 .702 & $8,99 \%$ & 100 & 100 \\
\hline 1940 & 15.530 .819 & 3.068 .269 & 260.202 & 3.328 .471 & 21,435 & 122,26 & 291,28 \\
\hline 1950 & 18.826 .409 & 4.366 .792 & 477.434 & 4.924 .226 & $26,15 \%$ & 148,20 & 430,92 \\
\hline 1960 & 25.877 .643 & 7.458 .002 & 1.177 .427 & 8.635 .429 & $33.37 \%$ & 203,71 & 755,70 \\
\hline 1970 & 35.170 .643 & 13.906 .484 & 4.989 .776 & 18.896 .260 & $53,72 \%$ & 276,86 & $1.653,64$ \\
\hline
\end{tabular}

Fonte: Romanelli (1978, p. 64).

A autora, porém, relativiza esse avanço na expansão, segundo o qual, em 20 anos, a taxa de escolarização, na faixa etária de 5 a 19 anos, é duplicada. Romanelli (1978, p.64), salienta ainda que houve uma insuficiência desse alcance, afinal em 1970 “[...] 46,28\% da população escolarizável estava fora da escola [...]". Acrescenta-se a isso que parte expressiva deste último contingente estava no meio rural, conforme valores percentuais, na tabela seguinte.

Tabela 7 - População nos censos demográficos por situação de domicílio no Brasil, no Sudeste e em Minas Gerais, 1950-1970

\begin{tabular}{cccccccc}
\hline ANO & & 1950 & \multicolumn{2}{c}{1960} & \multicolumn{2}{c}{1970} \\
\hline País/UF & Brasil & Sudeste & $M G$ & Brasil & $M G$ & Brasil & $M G$ \\
\hline Rural & 33.161 .506 & & 5.459 .273 & 38.987 .526 & 5.995 .460 & 41.603 .839 & 5.447 .982 \\
$\%$ & 63,84 & & 70,15 & 54,92 & 60,20 & 44,02 & 47,04 \\
Urbana & 18.782 .891 & & 2.322 .915 & 32.004 .817 & 3.964 .580 & 52.904 .744 & 6.167 .113 \\
$\%$ & 36,16 & 29,85 & 45,08 & 39,80 & 55,98 & 52,96 \\
\hline Total & $\mathbf{5 1 . 9 4 4 . 3 9 7}$ & & $\mathbf{7 . 7 8 2 . 1 8 8}$ & $\mathbf{7 0 . 9 9 2 . 3 4 3}$ & $\mathbf{9 . 9 6 0 . 0 4 0}$ & $\mathbf{9 4 . 5 0 8 . 5 8 3}$ & $\mathbf{1 1 . 6 4 5 . 0 9 5}$ \\
\hline
\end{tabular}

Fonte: IBGE (1950; 1960; 1970).

Com efeito, a distribuição demográfica em Minas Gerais replicava o cenário nacional, em outros termos, sua população era maciçamente residente no campo. Esse alinhamento no cenário nacional, de acordo com o ponto de vista da distribuição demográfica, replicou-se no campo da educação de tal modo que a criação de escolas rurais - municipais - sofreu retração, ainda que, nos momentos de ascensão, tenha crescido mais que os grupos escolares. Na tabela, a seguir, apresentam-se dados pertinentes, nesse sentido. 
Tabela 8. Evolução do número de escolas em Minas Gerais, 1957-1971

\begin{tabular}{cccccc}
\hline & $\begin{array}{c}\text { ESCOLAS } \\
\text { URBANAS }\end{array}$ & $\%$ & $\begin{array}{c}\text { ESCOLAS } \\
\text { RURAIS }\end{array}$ & TOTAL & $\%$ \\
\hline 1957 & 2.812 & 25,38 & 8.268 & 11.080 & 74,62 \\
1958 & 2.852 & 25,23 & 8.451 & 11.303 & 74,77 \\
1959 & 2.985 & 25,15 & 8.885 & 11.870 & 74,85 \\
1960 & 2.945 & 23,25 & 9.722 & 12.667 & 76,75 \\
1961 & 2.853 & 22,51 & 9.819 & 12.672 & 77,49 \\
1962 & 2.923 & 21,52 & 10.658 & 13.581 & 78,48 \\
1963 & 2.724 & 19,56 & 11.200 & 13.924 & 80,44 \\
1964 & 3.082 & 19,62 & 12.628 & 15.710 & 80,38 \\
1965 & 3.445 & 21,29 & 12.736 & 16.181 & 78,71 \\
1966 & 3.044 & 18,44 & 13.461 & 16.505 & 81,56 \\
1967 & 2.934 & 17,43 & 13.895 & 16.829 & 82,57 \\
1968 & 3.044 & 18,98 & 12.998 & 16.042 & 81,02 \\
1969 & 3.125 & 18,52 & 13.753 & 16.878 & 81,48 \\
\hline 1970 & 3.223 & 19,97 & 12.913 & 16.136 & 80,03 \\
1971 & 3.262 & 19,08 & 13.830 & 17.092 & 80,92 \\
\hline
\end{tabular}

Fonte: IBGE (2010).

Ao observar o volume de escolas rurais frente ao número de escolas urbanas, podese deduzir que a expansão da escolarização, em Minas Gerais, resultou mais da ação municipal que da ação do estado. Vale observar que, ao estado, cabia criar grupos escolares, destinados basicamente às cidades. Em parte, pode-se supor que erguer escolas no campo fosse menos oneroso que construir escolas urbanas.

Isso significa que o dispêndio financeiro na construção de escolas com, no máximo, duas salas de aulas, dois banheiros e uma varanda tendia a ser inferior aos custos da construção de um grupo escolar. Igualmente, manter uma professora residindo na região onde se instalava a escola, também, significava investimentos menores em recursos humanos. Importa observar que, em alguns casos, o proprietário cedia moradia para a permanência da professora, durante a semana.

Em relação às escolas de Minas, verifica-se, na tabela seguinte, a média de professores atuantes em escolas das áreas urbana e rural. 
Tabela 9. Quantidade de professores por escola em Minas Gerais, 1957-1971

\begin{tabular}{|c|c|c|c|c|c|c|c|c|c|}
\hline & 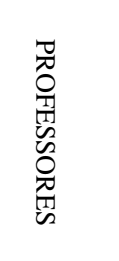 & $\begin{array}{l}\frac{\pi}{2} \\
2 \\
0 \\
5 \\
s\end{array}$ & 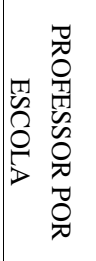 & 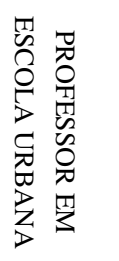 & 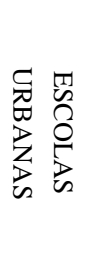 & 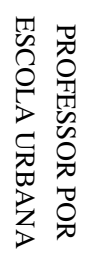 & 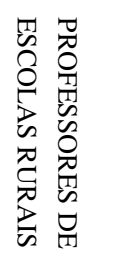 & 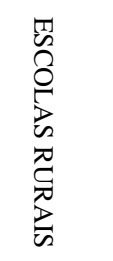 & 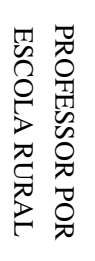 \\
\hline 1957 & 25.843 & 11.080 & 2,33 & 16.774 & 2.812 & 5,97 & 9.069 & 8.268 & 1,10 \\
\hline 1958 & 26.693 & 11.303 & 2,36 & 17.437 & 2.852 & 6,11 & 9.256 & 8.451 & 1,10 \\
\hline 1959 & 28.503 & 11.870 & 2,40 & 18.664 & 2.985 & 6,25 & 9.839 & 8.885 & 1,11 \\
\hline 1960 & 31.233 & 12.667 & 2,47 & 20.372 & 2.945 & 6,92 & 10.861 & 9.722 & 1,12 \\
\hline 1961 & 33.289 & 12.672 & 2,63 & 22.069 & 2.853 & 7,74 & 11.220 & 9.819 & 1,14 \\
\hline 1962 & 39.455 & 13.581 & 2,91 & 26.714 & 2.923 & 9,14 & 12.741 & 10.658 & 1,20 \\
\hline 1963 & 43.498 & 13.924 & 3,12 & 29.337 & 2.724 & 10,77 & 14.161 & 11.200 & 1,26 \\
\hline 1964 & 49.385 & 15.710 & 3,14 & 33.478 & 3.082 & 10,86 & 15.907 & 12.628 & 1,26 \\
\hline 1965 & 54.691 & 16.181 & 3,38 & 37.745 & 3.445 & 10,96 & 16.946 & 12.736 & 1,33 \\
\hline 1966 & 60.712 & 16.505 & 3,68 & 40.543 & 3.044 & 13,32 & 20.169 & 13.461 & 1,50 \\
\hline 1967 & 60.014 & 16.829 & 3,57 & 38.366 & 2.934 & 13,08 & 21.648 & 13.895 & 1,56 \\
\hline 1968 & 64.705 & 16.042 & 4,03 & 43.679 & 3.044 & 15,35 & 21.026 & 12.998 & 1,62 \\
\hline 1969 & 64.051 & 16.878 & 3,79 & 42.552 & 3.125 & 13,62 & 21.499 & 13.753 & 1,56 \\
\hline 1970 & 66.479 & 16.136 & 4,12 & 45.322 & 3.223 & 14,06 & 21.157 & 12.913 & 1,64 \\
\hline 1971 & 72.472 & 17.092 & 4,24 & 49.110 & 3.262 & 15,06 & 23.362 & 13.830 & 1,69 \\
\hline
\end{tabular}

Fonte: IBGE (1972).

Conforme os dados apresentados na tabela, em 1957,havia uma média de 2,33\% professores por escola; em 1971, 4,24\%. No meio rural, essa relação era 1,1\% e 1,69\%, respectivamente. Pode-se concluir que as escolas urbanas tiveram mais investimento em sua estrutura física e em recursos humanos, ou seja, podiam, estruturalmente, absorver mais alunos. As escolas rurais mantiveram quase a mesma estrutura física. A partir disso, pode-se inferir uma possível preparação para demandas futuras, como aquela derivada da migração campo-cidade.

[...] Minas Gerais sofreu ao longo de três décadas (1950-1970) uma significativa redução da sua população rural. Através dos dados utilizados, percebemos efetivamente um decréscimo no número de pessoas presentes no meio rural com uma população urbana em crescimento. Os dados do Censo Demográfico da década de 1950 apontam que $70 \%$ da população mineira viviam no meio rural. Entretanto, ao analisar os dados de 1960, essa porcentagem cai para $60 \%$, chegando à década de 1970 com $47 \%$ da população vivendo no meio rural mineiro (PORTES; SANTOS, 2012, p. 409).

Não obstante, a ascensão do número de escolas rurais - sobretudo em 1971 contrasta com o que Portes e Santos (2012) apontam. Em outros termos, esses autores questionam o seguinte: em um processo de êxodo do campo, na década de 1970, a quem se destinariam as escolas criadas no meio rural? Possivelmente, isso pode ser explicado, uma vez considerando que o processo de migração campo-cidade, em Minas Gerais, não ocorreu de forma uniforme em todo o estado. Em certas regiões, o êxodo pode ter sido menos severo, a exemplo de áreas menos desenvolvidas economicamente como o Vale do Jequitinhonha, onde as cidades talvez oferecessem pouco ao migrante e, de resto, à população nativa. Houve, ainda, municípios cuja população rural aumentou em razão da migração que recebera de regiões mineiras e outros estados, por exemplo, Ituiutaba. 


\section{Ituiutaba no contexto da expansão educacional}

O instrumento central da expansão educacional - o grupo escolar, sobretudo na primeira metade do século - privilegiou a cidade, onde se materializaram as relações sociais, econômicas e políticas, bem como as relações pessoais, cujos registros materiais podem ajudar a compreender a ampliação da escola pública. A possibilidade de desenvolvimento prometida pela cidade - pela educação de qualidade do grupo escolar, pelo emprego na indústria, pelas condições menos insalubres de vida - atraiu a população campesina, cuja presença na urbe modificaria sua feição, principalmente, a educacional, pois ampliava o número de analfabetos. Daí, ser necessidade incontestável a massificação educacional, sobretudo, a partir de 1940, quando o desenvolvimento no interior passou a ser visto como possibilidade de concretizar um projeto de unidade e homogeneidade nacional, principalmente, de políticas públicas para a educação.

Ituiutaba ilustra esse processo. Conforme o recenseamento geral de 1950, sua população era de 37.245 habitantes, cuja área de residência e grau de escolarização se delineiam nas tabelas, a seguir:

Tabela 10. População rural e urbana do município de Ituiutaba, 1940-1970

\begin{tabular}{rccccc}
\hline ANO & POPULAÇÃO RURAL & $\%$ & POPULAÇÃO URBANA & $\%$ & TOTAIS \\
\hline 1940 & 30.696 & $88 \%$ & 4.356 & $12 \%$ & 35.052 \\
1950 & 43.127 & $81 \%$ & 10.113 & $19 \%$ & 53.240 \\
1960 & 39.488 & $55 \%$ & 31.516 & $45 \%$ & 71.004 \\
1970 & 17.542 & $27 \%$ & 47.114 & $73 \%$ & 64.6568 \\
\hline
\end{tabular}

Fonte: IBGE (1940; 1950; 1960; 1970).

De acordo com os dados apresentados, na tabela acima, evidencia-se uma população rural superior à urbana. Em parte, por conta da migração de nordestinos, iniciada na década de 1950. Com efeito, a partir de 1950, a atividade agrícola (cultivo de grãos), cujo apogeu ocorreu nas décadas de 1950 e 1960 (RIBEIRO; LIMA; QUILLICI NETO, 2013), embasou a economia e estimulou o comércio: a cidade abastecia o estado. Ituiutaba "[...] já era a maior produtora de arroz e de milho em todo o Estado de Minas Gerais, com cerca de 10.000 alqueires (mineiros) de arroz, sendo cultivados". Seria chamada de "capital do arroz" até o fim do decênio de 1960 (SILVA, 1997, p. 26). Publicações, como a Enciclopédia dos municípios brasileiros (1959, p. 306), salientaram esse potencial agrícola:

A principal atividade do município é a agricultura. As terras [...] são reputadas, entre as mais ferazes do mundo, comparadas segundo Humboldt, Saint-Hilaire e Edward Miliward, às da Ucrânia, na Rússia, e as do Vale do São Lourenço, no Canadá. O Cultivo em toda a zona obedece a um alto nível de mecanização, possuindo Ituiutaba mais de meio milhar de tratores, bem como numerosas colhedeiras de arroz, o que lhe vale o título de "capital do arroz" (Grifo do autor).

As tabelas seguintes enumeram e quantificam as atividades econômicas, na década de 1950. A partir da leitura desses dados, pode-se deduzir que, em um município de população original maciçamente rural e ainda inflada por migrantes, era natural a concentração da atividade agrícola e pecuária como base da economia local, ou seja, da "capital do arroz". Os números referentes ao rebanho bovino e suíno dão uma medida da demanda por mão de obra. 
Tabela 11. Rebanhos do município de Ituiutaba, 1955

\begin{tabular}{cccc}
\hline REBANHOS & NÚMERO DE CABEÇAS & Cr\$ 1.000 & \% SOBRE O TOTAL \\
\hline Aves & 20 & 80 & 0,01 \\
Bovinos & 200.000 & 360.000 & 75,39 \\
Caprinos & 3.200 & 384 & 0,08 \\
Eqüinos & 15.000 & 18.000 & 3,76 \\
Muares & 2.500 & 3.000 & 0,62 \\
Ovinos & 1.600 & 272 & 0,05 \\
Suínos & 120.000 & 960.000 & 20,09 \\
\hline Total & - & 477.736 & 100 \\
\hline
\end{tabular}

Fonte: Enciclopédia dos municípios brasileiros (1959, p. 307).

Atividades econômicas de destaque no decênio de 1950, a agricultura e a pecuária tinham, nos homens, sua mão de obra preferencial; enquanto às mulheres couberam atividades domésticas e atividades escolares discentes; elas somavam 45,46\% da população. Souza e Silveira (2012, p. 4) reiteram esses dados, ao apontar que os migrantes "[...] buscaram escolarizar seus filhos, entretanto, eram as meninas, que de certa forma, tiveram maior incentivo a se escolarizarem, pois os meninos deveriam trabalhar na lavoura junto ao pai contribuindo com o sustento familiar". Conforme a tabela, a seguir, a maior parte da população masculina, acima de 10 anos de idade, estava na atividade agrícola, pecuária e silvicultura. Ou seja, a concentração da força do trabalho masculina era maior no meio rural.

Tabela 12. Atividades principais desenvolvidas em Ituiutaba, 1950

\begin{tabular}{|c|c|c|c|c|}
\hline \multirow{2}{*}{$\begin{array}{l}\text { ATIVIDADES PRINCIPAIS } \\
\text { DESENVOLVIDAS }\end{array}$} & \multicolumn{4}{|c|}{ POPULAÇÃO 10 ANOS OU MAIS } \\
\hline & Mulheres & Homens & $\begin{array}{l}\text { Números } \\
\text { absolutos }\end{array}$ & \% sobre o total geral \\
\hline $\begin{array}{l}\text { Atividades domésticas, } \\
\text { não remuneradas e } \\
\text { atividades escolares } \\
\text { discentes }\end{array}$ & 15.021 & 1.365 & 16.386 & 45,46 \\
\hline Atividades sociais & 93 & 77 & 170 & 0,48 \\
\hline Prestação de serviços & 802 & 516 & 1.318 & 3,73 \\
\hline $\begin{array}{l}\text { Indústria de } \\
\text { transformação }\end{array}$ & 21 & 922 & 943 & 2,67 \\
\hline $\begin{array}{l}\text { Comércio de } \\
\text { mercadorias }[\ldots]\end{array}$ & 28 & 503 & 531 & 1,50 \\
\hline $\begin{array}{l}\text { Transportes, } \\
\text { comunicações e } \\
\text { armazenagens }\end{array}$ & 4 & 333 & 337 & 0,95 \\
\hline Comércio de imóveis & 2 & 69 & 71 & 0,20 \\
\hline Profissões liberais & 5 & 72 & 77 & 0,21 \\
\hline $\begin{array}{l}\text { Administração pública, } \\
\text { legislativo e justiça }\end{array}$ & 8 & 43 & 51 & 0,14 \\
\hline $\begin{array}{l}\text { Agricultura, pecuária e } \\
\text { silvicultura }\end{array}$ & 141 & 13.016 & 13.157 & 37,26 \\
\hline Indústrias extrativas & - & 26 & 26 & 0,07 \\
\hline $\begin{array}{l}\text { Defesa nacional e } \\
\text { segurança pública }\end{array}$ & - & 16 & 16 & 0,04 \\
\hline Condições inativas & 825 & 1.398 & 2.223 & 6,29 \\
\hline TOTAL & 16.950 & 18.356 & 35.306 & 100,0 \\
\hline
\end{tabular}

Fonte: Enciclopédia dos municípios brasileiros (1959, p. 306).

Com efeito, Silveira (2012, p. 1) esclarece que, nos decênios de 1950 e 1960, um "[...] significativo processo de desenvolvimento agrário-industrial [...]" aconteceu em Ituiutaba e 
região, onde a fertilidade da terra se abria ao desenvolvimento da "[...] cultura de cereais, primordialmente o arroz, estimulando, assim, a indústria de beneficiamento de grãos, gerando no âmbito econômico, importante crescimento para o pontal mineiro". Para essas terras de economia promissora, houve uma migração expressiva de famílias inteiras que buscavam uma vida nova, dentre as quais, muitas que, por conta da seca, deixaram sua terra natal. Daí, a explosão demográfica no campo, cuja população feminina e masculina era quatro vezes maior que a do meio urbano. Para trabalhar nas lavouras de arroz e milho, os fazendeiros tiveram de buscar mão de obra fora do município, sobretudo, em regiões mais pobres de $\operatorname{Minas}^{3}$ e do Nordeste ${ }^{4}$.

Até o final da década de 1960, Ituiutaba e região receberam migrantes de lugares distintos, mas predominantemente do Rio Grande do Norte e da Paraíba. Nesse contexto de aumento populacional, o analfabetismo chegou a 57,35\%, na década de 1950 , taxa superior à do estado, então de $56,19 \%$. No meio rural, o percentual ascendia a $64,37 \%$, maior que o da cidade, $28,68 \%$, como mostra a tabela, a seguir.

Tabela 13. Quantitativo de pessoas alfabetizadas em Ituiutaba - 1950

\begin{tabular}{llccccc}
\hline \multirow{2}{*}{ DISCRIMINAÇÃO } & \multicolumn{4}{c}{ PESSOAS PRESENTES, DE 5 ANOS DE IDADE OU MAIS } \\
\cline { 3 - 7 } & & \multicolumn{3}{c}{ Números absolutos } & \multicolumn{2}{c}{ \% sobre o total } \\
\cline { 3 - 6 } & Total & $\begin{array}{c}\text { Sabem ler e } \\
\text { escrever }\end{array}$ & $\begin{array}{c}\text { Não sabem } \\
\text { ler e escrever }\end{array}$ & $\begin{array}{c}\text { Sabem ler e } \\
\text { escrever }\end{array}$ & $\begin{array}{c}\text { Não sabem } \\
\text { ler e escrever }\end{array}$ \\
\hline Quadro & Homens & 4.032 & 3.115 & 917 & 77,25 & 22,75 \\
urbano & Mulheres & 4.445 & 2.931 & 1.514 & 65,93 & 34,07 \\
& Total & 8.477 & 6.046 & 2.431 & 71,32 & 28,68 \\
Quadro & Homens & 18.300 & 7.116 & 11.184 & 38,88 & 61,12 \\
rural & Mulheres & 16.312 & 5.218 & 11.094 & 31,98 & 68,02 \\
& Total & 34.612 & 12.334 & 22.278 & 35,63 & 64,37 \\
Em geral, & Homens & 22.332 & 10.231 & 12.101 & 45,81 & 54,19 \\
& Mulheres & 20.757 & 8.149 & 12.608 & 39,25 & 60,75 \\
& Total & 43.089 & 18.380 & 24.609 & 42,65 & 57,35 \\
\hline
\end{tabular}

Fonte: Enciclopédia dos municípios brasileiros (1959, p. 308).

Como se lê na tabela apresentada, a maior porcentagem de pessoas com idade acima de 5 anos que não sabia ler nem escrever encontrava-se no meio rural. Isso possivelmente justifica a iniciativa de criação, por parte do município, de várias escolas rurais, no período de 1951 a 1972, bem como da primeira escola municipal urbana, autorizada a funcionar pela Portaria 7.869. Os dados, na tabela, a seguir, possibilitam uma medida em relação ao número de escolas municipais, a qual permite afirmar que houve mais uma política de prefeitos que de governadores. Assim, no que se refere ao analfabetismo no Brasil, tem-se o seguinte:

Tabela 14. Escolas - evolução do analfabetismo no Brasil, de 1940 a 1970

\begin{tabular}{lcccccc}
\hline Anos & $\begin{array}{c}\text { População } \\
\text { de mais de } \\
\text { 15 anos }\end{array}$ & $\begin{array}{c}\text { Analfabeto } \\
\text { de mais de } \\
\text { 15 anos }\end{array}$ & $\begin{array}{c}\text { Taxa de } \\
\text { analfabetis } \\
\text { mo }\end{array}$ & $\begin{array}{c}\text { População } \\
\text { de 15 a 39 } \\
\text { anos }\end{array}$ & $\begin{array}{c}\text { Analfabetos } \\
\text { de 15 a 19 } \\
\text { anos }\end{array}$ & $\begin{array}{c}\text { Taxa de } \\
\text { Analfabe } \\
\text { tismo. }\end{array}$ \\
\hline $\mathbf{1 9 4 0}$ & 23.639 .769 & 13.279 .899 & 56,17 & $16.515 . .300$ & 8.937 .282 & 54,11 \\
$\mathbf{1 9 5 0}$ & 30.249 .423 & 15.272 .432 & 50,48 & 20.911 .777 & 9.964 .060 & 47,64 \\
$\mathbf{1 9 6 0}$ & 40.187 .590 & 15.815 .903 & 39,35 & 27.017 .011 & 9.422 .610 & 34,87 \\
$\mathbf{1 9 7 0}$ & 54.336 .606 & 17.936 .887 & 33,01 & 35.954 .488 & 9.911 .744 & 27,56 \\
\hline
\end{tabular}

Fonte: Romanelli (1978, p. 75). 
De acordo com a tabela, acima, a população com mais de 15 anos, na década de 1940 apresentava uma taxa de analfabetismo de 54,11\%. Segundo Beisegel (2003), em 1940, a Educação de Jovens e Adultos começa a ganhar espaço na história da educação brasileira, com uma nova política voltada para esse contingente educacional. Romanelli (1978, p.75) menciona que: “[...] em números absolutos, cresceu o analfabetismo, porém em números relativos, ele decresceu sensivelmente". É importante observar que esta análise se refere ao analfabetismo no período de 1940 a 1970.

Em relação ao decênio de 1950, com a população de mais de 15 anos, o decréscimo do analfabetismo foi apenas de 6,31\%; Conforme Teixeira $(1989$, p.6), a explicação para essa diminuição de $6,31 \%$ da taxa de analfabetismo é um tanto alarmante:

Para isso demonstrar não preciso mais do que apresentar algumas cifras: Tínhamos, em 1900, 9.750.000 habitantes de mais de 15 anos, dos quais 3.380.000 eram alfabetizados e 6.370 .000 analfabetos. Em 1950, 14.900.000 eram alfabetizados e 15.350.000, analfabetos. Diminuímos a percentagem de analfabetos de $65 \%$ para $51 \%$, em cinquienta anos, mas em números absolutos, passamos a ter bem mais do dobro de analfabetos. Se considerarmos o analfabeto, como seria lícito considerar, um elemento mais negativo do que positivo na população, a situação brasileira, do ponto de vista da educação comum, tornou-se em 1950 pior do que em 1900 [...]. Bendito seja o nosso crescimento demográfico que anula o nosso pequeno esforço em aumentar as oportunidades de educação primária, sem lhe tirar, por isto mesmo, o caráter de educação seletiva! (TEIXEIRA, 1989, p. 6).

Nessa perspectiva, conforme Tabela 14, o decréscimo do analfabetismo verificado, quando os números em termos absolutos são analisados, é, de fato, desanimador. Esses números refletem o esforço para aumentar a oportunidade relativa à educação, no entanto, o crescimento demográfico intenso impede essa tentativa, demonstrando, assim, o caráter seletivo da educação brasileira.

Nos decênios de 1960 e 1970, em razão do funcionamento de classes de ensino supletivo e do Movimento Brasileiro de Alfabetização (MOBRAL), a Tabela 14 aponta um decréscimo do analfabetismo. No entanto, há de se considerar o alerta de Teixeira (1989) quanto à densidade demográfica, a qual é responsável pela exclusão escolar de muitos jovens e adultos em decorrência do trabalho e das dificuldades próprias da vida.

Em termos comparativos, apresenta-se, na tabela seguinte, a taxa de analfabetismo nos Estados brasileiros. 
Tabela 15. Taxa de Analfabetismo nos Estados brasileiros, segundo recenseamento de 1950

\begin{tabular}{lcll}
\hline \multicolumn{1}{c}{ Estados } & $\mathbf{\%}$ & \multicolumn{1}{c}{ Estados } & \% \\
\hline Guaporé $^{5}$ & 50,08 & Paraíba & 70,82 \\
Acre & 65,62 & Pernambuco & 68,25 \\
\hline Amazonas & 57,17 & Alagoas & 76,55 \\
Rio Branco $^{6}$ & 55,50 & Sergipe & 66,37 \\
Pará & 51,29 & Bahia & 68,45 \\
Paraná & 47,32 & R. G. do Sul & 37,78 \\
Goiás & 66,76 & Minas Gerais & 56,19 \\
Amapá & 55,92 & Espirito Santo & 52,99 \\
Maranhão & 74,78 & E. do Rio & 44,03 \\
Piauí & 74,11 & D. Federal & 15,44 \\
Ceará & 68,82 & S. Paulo & 34,70 \\
R. G. do Norte & 68,02 & M. Grosso & 43,73 \\
S. Catarina & 35,89 & & \\
\hline
\end{tabular}

Fonte: Moura Sobrinho (2002, p.94).

Com base na Tabela 15, pode-se identificar que os Estados brasileiros sofriam com os altos índices de analfabetismo na década de 1950, quando Minas Gerais apresentava mais da metade da população analfabeta - 56,19\%; sendo Alagoas o Estado brasileiro com a maior taxa de analfabetismo, 76,55\%.

Nesta perspectiva, frente ao crescimento populacional do município de Ituiutaba, na Tabela 13, apresenta-se a taxa de analfabetismo desse município, a qual demonstra que, em relação ao estado de Minas Gerais, o analfabetismo dessa cidade atingiu 57,35\%, sendo superior ao do estado Minas Gerais. Com isso, considera-se pertinente a problemática de estudo que essa pesquisa apresenta, uma vez que analisa a contradição existente em relação ao município que se destaca como a "Capital do Arroz", portanto, economicamente pujante, mas com um índice de analfabetismo superior ao do estado mineiro. 
Tabela 16. Criação das Escolas municipais rurais de Ituiutaba, 1941-1968

\begin{tabular}{|c|c|c|}
\hline ESCOLAS MUNICIPAIS & DATA DE CRIAÇÃO & LOCALIZAÇÃO \\
\hline E. M. Alberto Torres & Decreto-lei 73, de 25/11/41 & Água Suja \\
\hline E. M. Duque de Caxias & Decreto-lei 73, de 25/11/41 & Córrego da Canoa \\
\hline E. M. José Bonifácio & Decreto-lei 73 , de 25/11/41 & Córrego do Açude \\
\hline E. M. Quirino de Morais & Decreto-lei 73 , de 25/11/41 & Mateirinha \\
\hline E. M. São Francisco de Assis & Decreto-lei 73, de 25/11/41 & Córrego do Retirinho \\
\hline E. M. Augusto Alves Vilela & Decreto-lei 178, de 6/3/47 & Córrego da Divisa \\
\hline E. M. Francisco Alves Vilela & Decreto-lei 178 , de 6/3/47 & Campo Alegre \\
\hline E. M. Prefeito Jaime Meinberg & Decreto-lei 182 , de 19/6/47 & Ribeirão dos Baús \\
\hline E. M. Antonio Pedro Guimarães & Lei 119, de $24 / 11 / 51$ & Córrego do Macaco \\
\hline E. M. Constâncio F. de Almeida & Lei 119 , de $24 / 11 / 51$ & Cotia \\
\hline E. M. Francisco A. de Lorena & Lei 119 , de $24 / 11 / 51$ & Vila Fisa \\
\hline E. M. José Inácio de Souza & Lei 119 , de $24 / 11 / 51$ & Campo Alegre \\
\hline E. M. Joaquim José Domingues & Lei 347 , de $28 / 11 / 55$ & Fazenda Santa Rita \\
\hline E. M. Tiradentes & Lei 347 , de $28 / 11 / 55$ & Córrego Açude \\
\hline E. M. Hilarião Chaves & Lei 559 , de $21 / 3 / 60$ & Salto de Morais \\
\hline E. M. Antonio Joaquim da Costa & Lei 637 , de $25 / 3 / 61$ & Ribeirão dos Baús \\
\hline E. M. Santa Rita & Lei 673 , de $1 \% / 12 / 61$ & Santa Rita \\
\hline E. M. Antonio Baduy & Decreto 240 , de 22/2/62 & Campo Alegre \\
\hline E. M. Castro Alves & Decreto 241 , de 23/2/62 & Ponte Rio Prata \\
\hline E. M. São José & Decreto 249 , de 23/4/62 & Córrego da Mamoma \\
\hline E. M. João da Fonseca Filho & Decreto 261 , de $16 / 8 / 62$ & Boa Esperança \\
\hline E. M. Aureliano J. Freitas Franco & Decreto 264 , de 20/8/62 & São Lourenço \\
\hline E. M. Capela N. S. Aparecida & Decreto 312 , de 4/5/64 & Monte Azul \\
\hline E. M. Getúlio Vargas & Decreto 312 , de 4/5/64 & Baixadão \\
\hline E. M. Ver. Diógenes de Souza & Decreto 312 , de $4 / 5 / 64$ & Pontinhas \\
\hline E. M. Pref. José A. de Paula & Decreto 312 , de 4/5/64 & Guabiroba \\
\hline E. M. Fernando M. de Andrade & Lei 954 , de 29/3/65 & São Bento \\
\hline E. M. Dep. Daniel de F. Barros & Decreto 385 , de 15/4/66 & Açude \\
\hline E. M. Dr. Camilo Chaves Júnior & Decreto 385 , de $15 / 4 / 66$ & Sapé \\
\hline E. M. Joaquim José de Assis & Decreto 385 , de $15 / 4 / 66$ & Campo Alegre \\
\hline E. M. Domingos José Franco & Decreto 404 , de $27 / 12 / 66$ & Ribeirão São Vicente \\
\hline E. M. Manoel Alves Vilela & $\begin{array}{l}\text { Decreto municipal } 404 \text {, de } 27 / 12 / 66 \text {; autorização } \\
\text { de funcionamento pela portaria } 013 / 80 \text { de } 25 / 10 / 80\end{array}$ & $\begin{array}{l}\text { R. Francisco M. de } \\
\text { Andrade, Conjunto Sol } \\
\text { Nascente II }\end{array}$ \\
\hline E. M. Francisco José de Carvalho & Decreto 432 , de 23/8/67 & Capão Rico \\
\hline E. M. Antonio Severino da Silva & Decreto 454 , de $12 / 2 / 68$ & Rib. São Vicente \\
\hline E. M. Augusto Martins de Andrade & Decreto 454 , de 12/2/68 & $\begin{array}{l}\text { Pontal - Campo } \\
\text { Alegre }\end{array}$ \\
\hline E. M. João José dos Santos & Decreto 1.235 , de 21/6/68 & Córrego da Chácara \\
\hline E. M. Manoel Afonso Cancella & Decreto 492 , de $8 / 7 / 68$ & Ribeirão de S. Rita \\
\hline E. M. Antonio de Souza Martins & Decreto 503 , de $14 / 8 / 68$ & Alto do Carmo \\
\hline E. M. Cândido José de Carvalho & Decreto 507 , de 19/8/68 & Mangalarga \\
\hline E. M. Joaquim Antonio de Morais & Decreto 520 , de 19/9/68 & Córrego do Retiro \\
\hline E. E. M. José da Silva Ramos & Decreto 534 , de 2/12/68 & Córrego da Chácara \\
\hline $\begin{array}{l}\text { E. M. de } 1^{\circ} \text { e } 2^{\circ} \text { Graus Machado de } \\
\text { Assis }\end{array}$ & $\begin{array}{l}\text { Decreto } 73 \text {, de } 25 \text { de novembro de } 1941 \text {, recebe a } \\
\text { denominação de Machado de Assis. Lei municipal } \\
\text { 1.254, de 1968; autorização de funcionamento pela } \\
\text { portaria } 78 / 69 \text {, publicada no "MG", de } 8 / 3 / 69 \text {; em } \\
\text { 1973, implantação do regime instituído pela lei } \\
\text { federal 5.692, de } 11 / 8 / 71 \text {, modificando o } \\
\text { regimento conforme resolução } 146 / 72 \text {, aprovada } \\
\text { em 22/6/72, pelo Conselho Estadual de Educação } \\
\text { (MG) }\end{array}$ & Rua 26, Centro \\
\hline
\end{tabular}

Fonte: Ituiutaba (2015, [n.p.]).

Como se pode deduzir da fala do arquiteto que projetou e idealizou espaços para construir as primeiras escolas rurais de alvenaria do município de Ituiutaba, a quantidade não equivalia à qualidade. Vereador de Ituiutaba e colaborador do então prefeito, Samir 
Tannus (1967-1970), Fued José Dib defendeu seus projetos na Câmara e foi participante ativo das discussões e decisões de sua empreendedora gestão. Suas palavras dão uma medida de como era a estrutura física das escolas rurais, nas décadas de 1950 e 1960, assim como o transporte do professor e sua moradia:

Na década de 50, tinha escola rural que funcionava no paiol. Quando o Samir Tannus se elegeu, em 1966, para prefeito, com seu plano de governo "Uma escola em cada 58 dias de governo", eu o apresentei o programa de construção de prédios de alvenaria. E fizemos isso, criamos um bocado de escola. [...] As escolas eram muito simples, era um cômodo aqui outro ali, um banheirinho no meio, uma varandinha, no máximo duas salas de aulas; mas isso foi um progresso porque antes havia escola até no paiol. Tinha escola que funcionava era na casa do peão mesmo, sem espaço, sem um mínimo de conforto. A maioria dos professores morava na roça, geralmente o proprietário da fazenda cedia um lugar para o professor morar, na maioria das vezes era uma família que tinha filho que estudava. Agora, algumas escolas a prefeitura transportava. Não era uma norma que todos os professores morassem na zona rural, mas não quer dizer que a prefeitura garantia transporte para todos os professores. Tinha escola que às vezes tinha aluno de três séries, era uma professora só; primeiro porque muitas vezes eram poucos alunos. Não havia esforço para pôr aluno na escola. Era complicado (DIB, 2015, [n.p.]).

A solidez da fixação de parte expressiva dos migrantes nordestinos no campo começa a aluir no início do decênio de 1970, quando a cidade estava mais estruturada, e a produção de arroz já havia dado sinal de esgotamento. Além disso, no meio rural, impõe-se a mecanização, enquanto a pecuária de corte se sobrepõe à agricultura como base da economia, que buscava responder aos ditames do capitalismo de mercado e da lógica da lucratividade maior. Esse fenômeno provocou a concentração de renda entre os pecuaristas, a falência do comércio agrícola e o desemprego no campo, com o consequente êxodo rural. Daí, cabe dizer que a migração maciça campo-cidade, na região de Ituiutaba, não aconteceu nos anos de 1950-1960, mas, sim, a partir da década de 1970. Evidenciou-se a supremacia econômico-política de uma camada enriquecida, direta ou indiretamente, pela pecuária e, reconhecidamente, aguçada pelas propostas econômicas e práticas políticas dos governos militares, instalados após o golpe de 1964. Eclodiram novos meios de empreendimento urbano em razão da adaptação de segmentos sociais ao modelo econômico, sua política de subsídios e outros incentivos à iniciativa privada.

A supressão da atividade produtiva manual no campo levou uma quantidade expressiva de trabalhadores rurais - o pequeno produtor, o parceiro, o agregado, dentre outros atores que permeiam e movem a vida no campo - a se posicionar ante um dilema: ou migrar para outras regiões agrícolas e/ou industriais desenvolvidas, ou continuar no município como mão de obra disponível a modalidades de trabalho na área do comércio e de serviços na cidade, que, aliados a uma atividade industrial ainda incipiente, segundo Frattari Neto (2009), representou crescimento significativo na economia da cidade.

Muitos trabalhadores rurais rumaram-se para o meio urbano, em busca de trabalho e escola para os filhos. Segundo Silva (1997, p. 39), “[...] a partir de 1969 o 'tráfico de nordestinos' foi proibido pela Polícia Federal que intensificou a fiscalização, pondo fim ao pau de arara". Com o fim do ciclo da lavoura, os migrantes "[...] nordestinos passaram a habitar a periferia da cidade, transformando-se em bóias-frias, vigias, pedreiros, chapas, [tornaram-se] só trabalhadores, mas também pequenos empresários". A migração para a 
cidade inflou a população urbana, além de ter havido uma taxa de natalidade maior. Como mostra a Tabela 15, em três décadas, a população predominantemente rural passou a ser predominantemente urbana.

À parte os migrantes analfabetos que passaram a viver na cidade de Ituiutaba, a população urbana não migrante apresentava percentual elevado de analfabetismo, dado o número restrito de grupos escolares. Em geral, a cidade assemelhava-se a uma parcela expressiva de cidades mineiras e, quiçá, do país. Cabe salientar que a projeção econômica do município ocorreu antes mesmo do boom do arroz, pelo menos em Minas Gerais. Contudo, o destaque econômico, na primeira metade do século XX, não teve contrapartida na educação pública, pois os índices de analfabetismo eram expressivos, incoerentes com a expansão escolar nacional. Em 37 anos - entre a instalação do primeiro grupo escolar (1910) e a do segundo (1947), denominado Ildefonso Mascarenhas da Silva - houve falta de escolas públicas na educação do município. A essa carência correspondeu a presença da escola privada, decisiva na implementação de escolas primárias, de acordo com a tabela, a seguir.

Tabela 17. Escolas urbanas de Ituiutaba, 1900- 1940

\begin{tabular}{lll}
\hline PERÍODO & ESCOLA PÚBLICA & \\
\hline $1901-10$ & Grupo Escolar & Escola do professor José de Alencar \\
& João Pinheiro & Escola do professor Afonso José \\
& & Colégio Santa Cruz \\
& & Externato/Colégio São Luiz e Colégio Santo \\
& & Antônio \\
$1910-20$ & - & Não encontramos dados sobre escolas desse período \\
$1920-30$ & - & Colégio das Irmãs Belgas \\
& & Instituto Propedêutico Ituiutaba \\
& & Escola São José \\
$1930-40$ & & Instituto Marden \\
& & Colégio Menino Jesus de Praga \\
& & Colégio Santa Tereza \\
& Colégio São José \\
\hline
\end{tabular}

Fonte: Moraes (2004, p. 55).

Visto que, a partir da década de 1970, a migração para a cidade ganhou fôlego, a ida gradativa do campo para a sede municipal tendeu a esvaziar o campo da população em idade escolar; ou seja, levou à desativação de grande parte das escolas rurais, ao longo dos anos de 1970, por falta de aluno. Se não havia razão para mantê-las em funcionamento no meio rural, na cidade, o aumento da população era razão óbvia para a abertura de mais escolas públicas, ou seja, para a ação educacional do estado quanto à criação de grupos escolares. A tabela seguinte retrata o investimento realizado pelo governo mineiro na educação pública de Ituiutaba. 
Tabela 18. Criação e instalação de escolas estaduais de Ituiutaba -1908-1987

\begin{tabular}{|c|c|c|}
\hline NOME & CRIAÇÃO & INSTALAÇÃO/AUTORIZAÇÃO \\
\hline E. E. João Pinheiro & Decreto 2.327 , de 22/12/1908 & \\
\hline G. E. Ildefonso M. da Silva & Decreto 2.395 , de 31/1/1947 & \\
\hline G. E. Senador Camilo Chaves & Decreto 4.477 , de 21/03/55 & Data de instalação: 8/1/1956 \\
\hline E. E. Governador Clóvis Salgado & Decreto 4.966 , de 27/1/1956 & \\
\hline E. E. Arthur Junqueira de Almeida & Decreto 5.438 , de 18/4/1958 & \\
\hline E. E. Governador Bias Fortes & Decreto 005704 , de 27/11/1959 & $\begin{array}{l}\text { Ato de autorização publicado no } \\
\text { MG } 29 / 11 / 1959 \text { e estadualizada } \\
\text { em } 1 \% / 4 / 1960\end{array}$ \\
\hline E. E. Cel. João Martins & Decreto-lei 6.044 , de 14/12/1960 & \\
\hline E. E. Cônego Ângelo & Decreto-lei 7.215, de 10/10/1963 & Ato de autorização 28/11/64 \\
\hline E. E. Cel. Tonico Franco & Decreto-lei 8.406, de 24/6/1965 & Ato de autorização 6/3/1966 \\
\hline E. E. Dr. Fernando Alexandre & Decreto-lei 8.407, de 24/6/1965 & Autorizado a funcionar em 25/3/1966 \\
\hline C. E. M. Dr. José Z. de Andrade & Lei 3.595 , de 25/11/1965 & \\
\hline E. E. Prof ${ }^{a}$. Maria de Barros & Lei 3.878 , de 20/12/1965 & \\
\hline E. E. Governador Israel Pinheiro & Lei 3.956 , de 23/12/1965 & \\
\hline E. E. Rotary, & Decreto, 9.703 de 6/04/1966 & \\
\hline E. E. Prof. Álvaro B. de Andrade & Decreto, 11.097 de 9/05/1968 & \\
\hline
\end{tabular}

Fonte: Ituiutaba (2015, [n.p]).

Possivelmente, os índices elevados de analfabetismo em Ituiutaba, no decênio de 1950 - superiores à média do estado, convém reiterar - justifiquem-se em razão da escassez de escola pública, pois, até 1954, a cidade contava com dois grupos escolares para 2,4 mil pessoas na faixa etária de 5 anos ou mais. Acrescente-se a esse contingente a população em idade escolar dos adultos analfabetos que ampliaram a população urbana de Ituiutaba em mais de 16 mil habitantes entre os anos de 1960 e 1970. O montante de matrículas inicial do Grupo Escolar Professor Ildefonso Mascarenhas, segundo relato de sua ex-diretora Nagib Moukachar (2009), foi de “[...] 400 e tantos alunos [...]". Assim, tomando 400 vagas como média inicial de matrícula das escolas públicas, criadas após esse grupo, então poder-se-ia pensar que a demanda de escolarização de 2,4 mil vagas somente seria suprida, em 1963.

De fato, em 1955, a construção de mais escolas foi objeto de discussão na Câmara Municipal. Como deixa entrever registro em ata, os debates frisaram a possibilidade de expansão dos grupos escolares mesmo sem apoio do governo mineiro:

$\mathrm{CM} / 1 / 55$, alegando que a situação financeira do município, não permite atender a este encargo, pois o mesmo é de competência do Estado. Com a palavra o vereador Sr. Pedro Lurdes de Moraes que diz: "tenhamos ou não auxílio do Estado, necessitamos de mais um grupo escolar". E pede assim que se vote unanimemente favorável à mensagem. Logo a seguir fala o vereador Sr. Dr. Daniel de Freitas Barros, que, depois de várias considerações sobre a necessidade de mais um grupo escolar para o município, pede que se vote favoravelmente (ITUIUTABA, 1955, [n.p]).

Diferentemente, ainda em 1955, o Poder Executivo manifestou-se contrariamente à construção de mais escolas, como se lê nesta passagem de ata da Câmara: 
Projeto CM/18/55, que dispõe sobre a criação de escolas e professores de autoria do vereador Antenor Tomaz Domingues com a palavra o Dr. Daniel de Freitas Barros que baseado em informações prestadas pela prefeitura municipal de que existem vinte escolas paralisadas por falta de professores, acha desnecessária, no momento a criação de mais escolas, que viriam onerar o município (ITUIUTABA, 1955, [n.p]).

O texto da ata não explicita quais escolas estavam paralisadas, mas presume-se que fossem rurais. Como se pode deduzir, havia descompasso: muitos alunos para poucas escolas; muitas escolas para poucos professores. Havia ainda um terceiro elemento: falta de prédio para instalar a escola, o que era uma ameaça ao funcionamento escolar, como se lê em notícia publicada pelo jornal Correio do Pontal (1957, p. 2):

Comenta-se aos bastidores da política local que o Grupo Escolar "Ildefonso Mascarenhas da Silva", que não tem prédio próprio, esteve ameaçado de ter suas atividades suspensas em 1957, porque o Estado estaria propenso a impedir o seu funcionamento no edifício do Grupo "João Pinheiro". A propósito, o dep. Omar Diniz chegou a enviar um telegrama ao Secretario da Educação, apelando para o Sr. Abguar Renault, no sentido de que permita a dupla ocupação do prédio, pelo menos por mais um exercício. $\mathrm{E}$ isto é o que vae suceder, tanto no corrente ano como nos próximos, porque o Estado nada constróe em Ituiutaba, que tem três grupos funcionando, mais um criado e sòmente um prédio escolar para abrigar a criançada de uma cidade de 21500 habitantes, séde de um município que rende mais 30 milhões para os seus cofres. A Constituição do país, no entanto, em seu Art. ${ }^{\circ} 168$, ítem I, prescreve a obrigatoriedade do ensino primário, e nossa lei eleitoral exige que o cidadão seja alfabetizado para poder votar - uma ironia revoltante, quando sabemos que o Estado, não apenas dificulta, mas impede totalmente a difusão do ensino. Ituiutaba em peso póde atestar essa contradição. E ainda seríamos felizes se fôsse apenas Ituiutaba... (Grifos do autor).

\section{Considerações finais}

No Brasil dos anos de 1950 e 1960, ocorreram transformações socioeconômicas e políticas que mudaram a feição das cidades, sobretudo, os fenômenos da industrialização e migração do meio rural para o meio urbano. Entender essas transformações urbanas supõe fazer o que preconiza Lefèbvre (1999): pensar na mediação do social entre o econômico e o político de modo a romper com interpretações esvaziadas, porque dispensam a subjetividade, o cotidiano, o vivido, a percepção etc. Assim, espera-se que as informações, os dados e a análise apresentados, por ora, permitam entender a razão pela qual cabe dizer que a universalização da educação pública e gratuita sempre enfrentou impasses no âmbito do Estado para se desenvolver; impasses advindos ora de interesses privados que o Estado representa - a elite econômica que dificulta um projeto público e universal de educação gratuita; ora do Estado, que se omite ante suas responsabilidades educacionais.

Em um estado privilegiado pela criação de grupos escolares, já nos primeiros anos do século XX, como Minas Gerais, essa expansão educacional - aumento na quantidade de salas de aulas e vagas - não supriu a demanda de toda a população escolarizável. Noutros termos, em municípios mineiros como Ituiutaba, foram criadas mais escolas municipais (rurais) do que estaduais; indicativo de um sentido inverso ao da expansão, de acabar com 
escolas isoladas, reunindo-as no grupo escolar. Embora tenham sido criadas escolas estaduais, o governo local investiu mais que o estadual. As contradições referentes a um município com índices econômicos elevados, tais quais os índices de analfabetismo superiores à média de Minas Gerais - mostram ser complexas, ou seja, algo com determinantes externos ao município, e não - como se poderia pensar - como evento localizado.

Em uma lógica de igualdade para todos, seria natural que o número de escolas rurais fosse superior ao de escolas da cidade. Só não parece natural a ênfase no grupo escolar como modelo de escola para a cidade, quando a população do país residia majoritariamente no campo. Em outras palavras, podia-se supor que, também, para o meio rural, houvesse um plano de educação que se alinhasse aos parâmetros daquele concebido para os citadinos. Diferentemente, ao volume de escolas rurais equivaleu certa precariedade nas condições de escolarização e funcionamento. Pelo fato de essas escolas serem geridas por fazendeiros, provavelmente poderiam ser submetidas a interesses político-partidários.

\section{Referências}

ARAUJO, José. Carlos Souza. Os grupos escolares em Minas Gerais como expressão de uma política pública: uma perspectiva histórica. In: VIDAL, Diana Gonçalves. (Org.). Grupos escolares: cultura escolar primária e escolarização da infância no Brasil (18931971). Campinas: Mercado de Letras, 2006, p. 206-249.

ARAUJO, Maria Marta de; MOREIRA, Keila Cruz. O Grupo Escolar Modelo "Augusto Severo" e a educação da criança (Natal-RN, 1908-1913). In: VIDAL, Diana Gonçalves (Org.). Grupos Escolares: cultura escolar primária e escolarização da infância no Brasil (1893-1971). Campinas: Mercado das Letras, 2006.

BESKOW, Paulo R. Agricultura e política no contexto brasileiro da industrialização do pós-guerra (1946-1964). Estudos, Sociedade e Agricultura, ano 12, p. 56-79, abr.1999.

BEISIEGEL, C. R A educação de jovens e adultos analfabetos no Brasil. Alfabetização e Cidadania, São Paulo, n. 16, p. 19-27, jul. 2003.

BEZERRA, Luciene Teresinha de Souza. Da Sombra da Magnólia ao porvir do Grupo Escolar Governador Clóvis Salgado de 1956 a 1971, 2016.121 f. Dissertação (Mestrado em Educação) - Faculdade de Educação, Universidade Federal de Uberlândia, Uberlândia, 2016.

BUFFA, Ester. História e filosofia das instituições escolares. Estudo dois. In: ARAÚJO, José Carlos Souza; GATTI JÚNIOR, Décio. (Orgs.). Novos temas em história da educação brasileira. Instituições escolares e educação na imprensa. Campinas: Autores Associados, 2002, p. 25-38.

ENCICLOPÉDIA dos municípios brasileiros - Rio de Janeiro: IBGE, 1959. v. XXV.

FRATTARI NETO, Nicola José. Educandário Espírita Ituiutaba: caminhos cruzados entre a ação inovadora e sua organização conservadora. Ituiutaba, Minas Gerais (1954-1973), 
2009.202 f. Dissertação (Mestrado em Educação) Faculdade de Educação, Universidade Federal de Uberlândia, 2009.

INSTITUTO BRASILEIRO DE GEOGRAFIA E ESTATÍSTICA. Censo demográfico 1940/1950. Quadro de totais referentes ao Estado e de distribuição segundo os municípios 1940/1950. Rio do Janeiro: Serviço gráfico do Instituto Brasileiro de Geografia e Estatística, 1950, Tomo XIX.

INSTITUTO BRASILEIRO DE GEOGRAFIA E ESTATÍSTICA. Censo demográfico 1960. Minas Gerais VII Recenseamento Geral do Brasil. Série Regional. Fundação Instituto Brasileiro de Geografia e Estatística. Departamento de Estatística de População, 1960, v. I.

INSTITUTO BRASILEIRO DE GEOGRAFIA E ESTATÍSTICA. Censo demográfico 1970. Minas Gerais VII Recenseamento Geral do Brasil. Série Regional. Fundação Instituto Brasileiro de Geografia e Estatística. Departamento de Estatística de População v. I. Tomo XIX.

INSTITUTO BRASILEIRO DE GEOGRAFIA E ESTATÍSTICA/IBGE. Serviço de Estatística da Educação e Cultura. Anuário estatístico do Brasil: 1957-1971. Rio de Janeiro: IBGE, 1972.

INSTITUTO BRASILEIRO DE GEOGRAFIA E ESTATÍSTICA. Censo demográfico 2010. Disponível em: < http://www.ibge.gov.br/home/estatistica/populacao/censo2010/resultados_gerais_amostra_ areas_ponderacao/default.shtm>. Acesso em: 15 set. 2015.

ITUIUTABA. Secretaria Municipal de Educação. [Dados sobre a criação e instalação de escolas estaduais de Ituiutaba]. Levantamento feito via Superintendência Regional de Ensino. Ituiutaba, MG, jun. 2015.

ITUIUTABA. Autorização de Funcionamento da Escola Municipal de $1^{\circ}$ e $2^{\circ}$ grau Machado de Assis. Portaria 78/69. Publicada no Minas Gerais no dia 8 de março de 1969.

LEFÈBVRE, Henri. A revolução urbana. Belo horizonte: UFMG, 1999.

MINAS GERAIS. Decreto nº 2.327 cria o Grupo Escolar de Villa Platina pelo vicepresidente Júlio Bueno Brandão e por Estevão Leite de Magalhães Pinto, no dia 22 de dezembro de 1908, e publicado no Minas Geraes - Orgão Official dos Poderes do Estado, Belo Horizonte, ano XVII, n. 304, p. 1, 23 dez.1908.

MORAES, Vera Cruz Oliveira. Tudo pela pátria: a história do instituto "Marden". 2004.150 f. Dissertação (Mestrado em Educação) - Faculdade de Educação, Universidade Federal de Uberlândia, Uberlândia, 2004.

MOURA SOBRINHO. Batista Vicente. Massificação do Ensino em Uberlândia MG: a fala da imprensa (1940 - 1960). 2002, 183 f. Dissertação (Mestrado em Educação) Faculdade de Educação, Universidade Federal de Uberlândia, Uberlândia, 2002. 
NOSELLA, Paolo; BUFFA, Ester. A pesquisa sobre instituições escolares.

Videoconferência promovida pelo HISTEDBR - 20 anos, UNICAMP, em 24/11/2005, interligada com o II Colóquio sobre Pesquisa e Instituições Escolares UNINOVE, São Paulo. Disponível em:

<http://www.histedbr.fe.unicamp.br/navegando/artigos_pdf/Paolo_Nosella_artigo.pdf>. Acesso em: 5 jan. 2016

PORTES, Écio Antônio; SANTOS, Apolliane Xavier Moreira dos. Aspectos da educação e do êxodo rural em Minas Gerais (1950-1970). Caderno de História da Educação, v. 11, n. 2, p. 409-15, jul./dez. 2012.

ROMANELLI, Otaíza de Oliveira. História da Educação no Brasil. 33. ed. Petrópolis: Vozes, 1978.

SAVIANI, Dermeval. História das ideias pedagógicas no Brasil. 2 ed. rev. e ampl. Campinas: Autores Associados, 2007, p. 303-50.

SILVA, Dalva Maria de Oliveira Memória: lembrança e esquecimento. Trabalhadores nordestinos no Pontal do Triângulo Mineiro (décadas de 1950 e 1960). 1997. 150.f Dissertação (Mestrado em História Social) - Programa de Pós-graduação da Pontifícia Universidade Católica de São Paulo, São Paulo, 1997.

SILVA, Suely Braga. 50 anos em 5: a odisséia desenvolvimentista do Plano de Metas. Disponível em:

<http://www.cpdoc.fgv.br/nav_jk/htm/o_brasil_de_jk/50_anos_em_5_o_plano_de_metas.a sp>. Acesso em: 30 out. 2015.

SILVEIRA, Daiane de Lima Soares. Migrantes nordestinas e escolarização no Pontal Mineiro (1950 a 1960): desafios, resistências, embates e conquistas. 2012. 148.f Dissertação (Mestrado em Educação) - Faculdade de Educação, Universidade Federal de Uberlândia, Uberlândia, 2012.

SKIDMORE, Thomas Elliot. Brasil: de Getúlio Vargas a Castelo Branco, 1930-1964. 14. ed. Rio de Janeiro: Paz e Terra, 2007.

TEIXEIRA, Anísio. A Educação não é privilégio. Revista Brasileira de Estudos

Pedagógicos, Rio de Janeiro, v.6, n.63, p.3-31, jul./set. 1956.

\section{Fontes}

FOLHA DE ITUIUTABA. Fontes Esteve ameaçado de paralisação o Grupo Ildefonso Mascarenhas. Ituiutaba, MG, 09/02/1957.

DIB, Fued José. Arquivo de mp3 (120 minutos). Luciene Bezerra. Ituiutaba, MG, 12 ago. 2015. Entrevista concedida a Luciene Bezerra na residência do entrevistado.

ITUIUTABA. Câmara Municipal de Ituiutaba. Ata da $11^{a}$ sessão da $3^{a}$ reunião ordinária da Câmara Municipal de Ituiutaba, realizada no dia 16 nov.1955. Livro [s.n.], [n.p.] 
MOUKACHAR, Nagib Bitar. 1 fita cassete (60 min.). Valéria Aparecida. Ituiutaba, MG, 4 de fev. 2009. Entrevista concedida a Valéria Aparecida na residência da entrevistada.

\section{Notas}

${ }^{1}$ Em 1954, a cidade contava com dois grupos escolares para 2,4 mil pessoas na faixa etária de 5 anos ou mais. O montante de matrículas inicial do Grupo Escolar Professor Ildefonso Mascarenhas, criado em 1947, segundo relato de sua ex-diretora Nagib Moukachar (2009), foi de "[...] 400 e tantos alunos [...]". Não temos dados do volume de matrículas abertas pelo Grupo Escolar João Pinheiro, o primeiro da cidade. Criado pelo Decreto 2.327, assinado em 22 de dezembro de 1908, começou a funcionar com o nome de Grupo Escolar de Villa Platina em 1910.

${ }^{2}$ Este estudo utiliza dados, leituras e reflexões realizados para a pesquisa de mestrado, materializada na dissertação, intitulada, Da sombra da magnólia ao porvir do Grupo Escolar Governador Clóvis Salgado de 1956 a 1971, defendida por Luciene Teresinha de Souza Bezerra, em fevereiro de 2015, na Universidade Federal de Uberlândia.

${ }^{3}$ Vieram famílias de Luz, da região do Alto Paranaíba, do Vale do Jequitinhonha e do Norte de Minas.

${ }^{4}$ O fluxo migratório de estados nordestinos para o Triângulo Mineiro foi abordado por SILVA (1997).

${ }^{5}$ Território Federal de Guaporé e depois batizado como Território Federal de Rondônia.

${ }^{6}$ Território Federal de Rio Branco - depois Território Federal de Roraima.

Recebido: Abril/2016.

Aprovado: Abril/2017. 